\title{
EFFECTS OF SERVANT LEADERSHIP OF CONSUMER'S COOPERATIVE MANAGER ON THE JOB SATISFACTION AND ORGANIZATIONAL COMMITMENT
}

\author{
Hongki Lee \\ Professor, Department of Management, \\ Jungwon University, Goesan Gun, South Korea \\ Ho-Kil Kang \\ Professor, Department of Marketing and Management, \\ Osan University, Osan, South Korea
}

\begin{abstract}
Human is the most essential factor in any organization. In most-updated and advancing society, the very core of a subject in human management is to show outstanding leadership to maximize the job satisfaction and job commitment among the employee so that they can effectively achieve the organizational goal yielding the duty result and productivity. It is suggested that one of the most important management Subject is to nurture outstanding leaders in organizational management. This research starts from the question as follows: "What kind of managerial leadership facilitates the job satisfaction and job commitment among the employee of consumer cooperative?" especially, it is necessary to study the effect of servant leadership in terms of the job satisfaction and job commitment among the employee of consumer cooperative. This research focuses on to verify the effect of servant leadership to the organizational effectiveness examining previous related subject; to verify if the trust facilitates the effect of servant leadership. As described in this research, it is suggested that the employee is very likely to follow the managerial direction with servant leadership combined with the trust yielding greater amount of job satisfaction and organizational satisfaction. The result of this study recommends that the individuals with effective leadership should be nurtured and appointed to the management or administrator position facilitating strategically management.
\end{abstract}

Key words: Consumer cooperative, Servant leadership, job satisfaction, job commitment 
Effects of Servant Leadership of Consumer's Cooperative Manager on the

Job Satisfaction and Organizational Commitment

Cite this Article: Hongki Lee and Ho-Kil Kang, Effects of Servant Leadership of Consumer's Cooperative Manager on the Job Satisfaction and Organizational Commitment, International Journal of Management, 11(12), 2020, pp 1028-1034. $\mathrm{http}: / /$ iaeme.com/Home/issue/IJM?Volume $=11 \&$ Issue $=12$

\section{INTRODUCTION}

Among recent leadership theories, there is a lot of interest in Servant Leadership in all industries. The servant leader starts with the idea that he is a servant. This comes from the premise that man has his own emotions to serve others. A true leader leads them while serving others. In order to verify that the current leader is a servant leader, it is necessary to analyze whether the member who is supported by the leader is growing personally, becoming wise, making more self-decision making, and whether the member is growing as a servant leader by himself. This perspective of Servant Leadership does not distinguish between the two fundamental perspectives of achieving a task and maintaining a relationship, but integrating the two within one framework. In other words, Servant Leadership is a concept in which achievement of tasks and maintenance of relationships are not viewed as contradictory concepts, but integrated into a leader's service behavior. [1-5] The behavioral characteristics of the servant leader are shown in Table 1 below.

Table 1 Servant Leader Behavioral Characteristics

\begin{tabular}{|r|c|}
\hline & Behavioral characteristics \\
\hline 1 & As a leader, you recognize yourself as a Servant or Support \\
\hline 2 & The organization recognizes that the most valuable resource is people \\
\hline 3 & Always show an attitude of learning \\
\hline 4 & Show an attitude of listening \\
\hline 5 & Always promote work through persuasion and dialogue \\
\hline 7 & Let the organization form a community \\
\hline
\end{tabular}

The purpose of this study is to review previous studies on the effect of Servant Leadership on organizational effectiveness, and to test the effect of Servant Leadership on organizational effectiveness and whether trust acts as a parameter to that effect. [6-10] The research questions to achieve that purpose are as follows.

Hypothesis 1: Servant Leadership will have a positive effect on trust in the boss.

Hypothesis 2: Trust will have a positive effect on job satisfaction.

Hypothesis 3: Trust will have a positive effect on organizational satisfaction.

Based on these hypotheses, first, it was investigated whether the Servant Leadership of the manager affects the organizational effectiveness. Second, we studied whether trust plays a 
mediating role in the influence of manager's Servant Leadership on organizational effectiveness.

\section{DISCUSSION}

Figure 1 shows the research model. In order to provide a method for effective organizational management, this study surveyed about 200 managers and employees of companies. And the influence of the manager's Servant Leadership on the trust, job satisfaction, and organizational satisfaction of members was studied. Data collection was conducted from October 1st to December 28th, 2018 with a structured questionnaire. The researcher personally visited the company and explained the contents of the questionnaire, and the subject was asked to fill out the questionnaire. The collected questionnaire was 182 out of the total 200 , showing a $90 \%$ recovery rate, but 29 of the collected questionnaires were excluded, and $153(76.5 \%)$ were used for analysis.

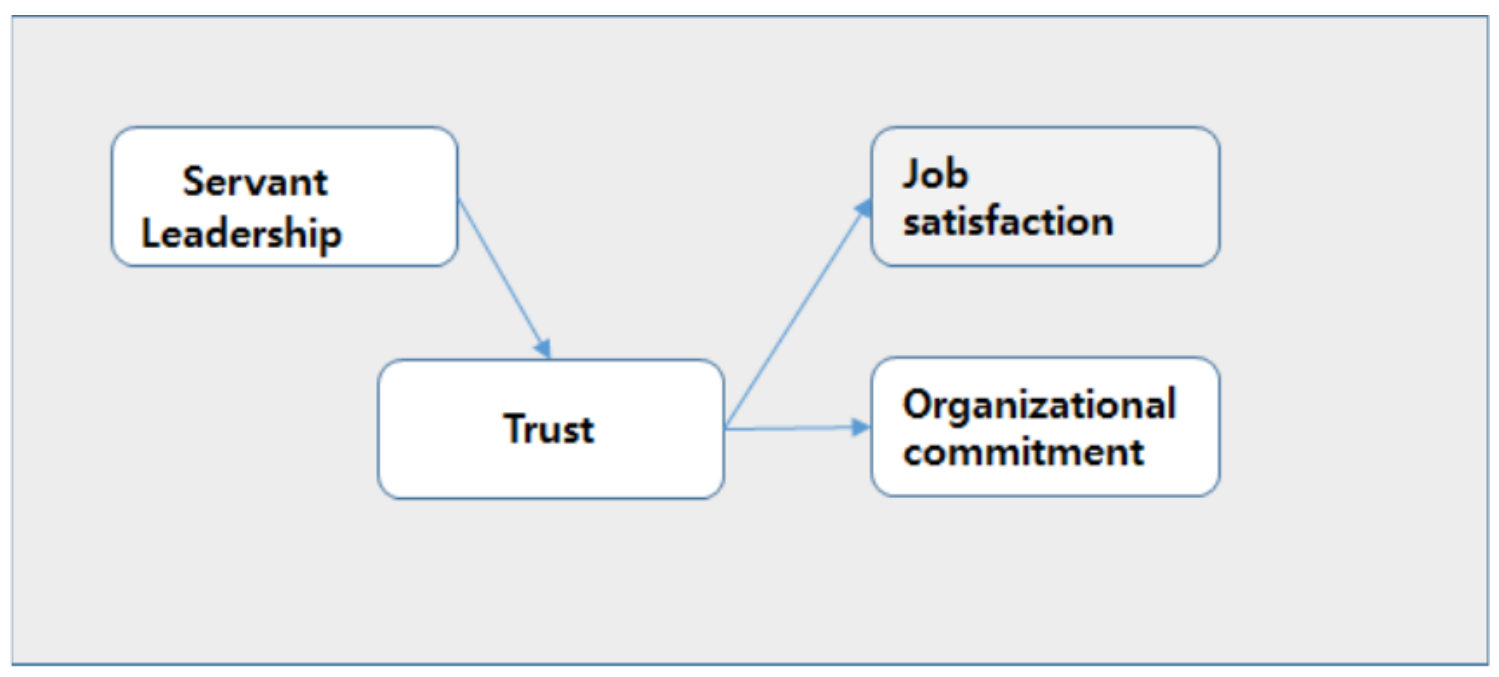

Figure 1 Research model

In this study, in order to understand the Servant Leadership of organizational leaders, based on the concept suggested by Greenleaf (1971), SOLA (Servant Organizational Leadership Assessment) was supplemented and used. [10]

For job satisfaction, the questionnaire was revised and supplemented based on the most widely used Minnesota Satisfaction Questionnaire (MSQ) and Job Descriptive Index (JDI). The survey was conducted on 200 workers. Among the collected questionnaires, the questionnaires with insufficient answers were discarded and 153 copies were used as analysis data. The demographic characteristics of the respondents were 105 males (68.6\%) and 48 females (31.4\%). By age, 15 people aged 25 and under (9.8\%), 44 people aged 26-30 (28.8\%), 56 people aged 31-35 (36.6\%), 21 people aged 36-40 (13.7\%), $17(11.1 \%)$ were over 40 years old. By educational background, $28(18.3 \%)$ high school graduates and $125(81.7 \%)$ college graduates or higher, and the level of education was generally high. Scaling is the process of developing meaningful units of measure and quantifying the measured results based on past experience. The purpose of this scaling is to assign people with the same attributes or attitudes to have the same score. There are the Thurstone scale method, the Likert scale method, and the Guttman scale method, among which the Likert scale method is most widely used. Reliability refers to the accuracy of a measurement. Cronbach's Alpha is widely used for reliability analysis to determine whether or not the internal consistency is maintained, and Cronbach's Alpha is also used to evaluate reliability in this study. Cronbach's Alpha represents the correlation between the measured items or the correlation between the measured score and the truth as a value 
Effects of Servant Leadership of Consumer's Cooperative Manager on the

Job Satisfaction and Organizational Commitment

between 0 and 1 , and usually, if the reliability is 0.5 or higher, the reliability is considered. In this study, it was judged that Cronbach's Alpha coefficient was more than 0.6 to be reliable.

Table 2 is the result of analyzing the reliability of the measured variables and items.

Table 2 Results of reliability analysis

\begin{tabular}{|c|c|c|c|}
\hline $\begin{array}{l}\text { Measured } \\
\text { variable }\end{array}$ & Measurement item & Alpha & $\begin{array}{c}\text { Cronbach's } \\
\text { Alpha }\end{array}$ \\
\hline \multirow{4}{*}{ trust } & $\begin{array}{l}\text { Overall, I firmly believe and follow the current } \\
\text { organization manager. }\end{array}$ & 0.8311 & \multirow{4}{*}{0.8516} \\
\hline & $\begin{array}{l}\text { Overall, the current organization manager is a } \\
\text { great help in my work life. }\end{array}$ & 0.7635 & \\
\hline & $\begin{array}{l}\text { Overall, I rely heavily on the current } \\
\text { organization manager when I need help. }\end{array}$ & 0.7622 & \\
\hline & $\begin{array}{l}\text { Overall, I don't trust the current organization } \\
\text { manager at all. }\end{array}$ & 0.8810 & \\
\hline \multirow{10}{*}{$\begin{array}{l}\text { Servant } \\
\text { leadership }\end{array}$} & $\begin{array}{c}\text { My boss accepts opinions and criticisms that } \\
\text { are different from his own. }\end{array}$ & 0.7886 & \multirow{3}{*}{0.8277} \\
\hline & $\begin{array}{c}\text { My boss takes his employees' opinions } \\
\text { seriously. }\end{array}$ & 0.7801 & \\
\hline & $\begin{array}{l}\text { My boss reflects the opinions of employees in } \\
\text { the policy. }\end{array}$ & 0.7967 & \\
\hline & $\begin{array}{l}\text { My boss listens to the employees and treats } \\
\text { them personally. }\end{array}$ & 0.8043 & \multirow{3}{*}{0.8778} \\
\hline & $\begin{array}{l}\text { My boss gives me a chance to improve my } \\
\text { work standard. }\end{array}$ & 0.7804 & \\
\hline & $\begin{array}{l}\text { My boss gives me some power to make me } \\
\text { more responsible. }\end{array}$ & 0.8346 & \\
\hline & My boss delegates to me to make decisions. & 0.5955 & \multirow{4}{*}{0.6801} \\
\hline & $\begin{array}{l}\text { My boss gives me the authority I need to do } \\
\text { my job. }\end{array}$ & 0.5711 & \\
\hline & $\begin{array}{l}\text { My boss lets me make decisions that I can take } \\
\text { responsibility for. }\end{array}$ & 0.6721 & \\
\hline & My boss doesn't overestimate his strengths. & 0.6086 & \\
\hline
\end{tabular}


Hongki Lee and Ho-Kil Kang

\begin{tabular}{|c|c|c|c|}
\hline \multirow{3}{*}{ Job satisfaction } & I am very interested in the work I am doing. & 0.7015 & \multirow{3}{*}{0.7491} \\
\hline & $\begin{array}{l}\text { I feel a sense of accomplishment while doing } \\
\text { my job. }\end{array}$ & 0.6933 & \\
\hline & $\begin{array}{l}\text { I am making good use of my knowledge and } \\
\text { skills in the work I am doing. }\end{array}$ & 0.5892 & \\
\hline \multirow{4}{*}{$\begin{array}{l}\text { Organizational } \\
\text { commitment }\end{array}$} & $\begin{array}{l}\text { I think the work I am doing is helpful for } \\
\text { promotion and development of skills. }\end{array}$ & 0.7678 & \multirow{4}{*}{0.7884} \\
\hline & $\begin{array}{l}\text { I think our organization is highly recognized } \\
\text { socially. }\end{array}$ & 0.7478 & \\
\hline & Our organization treats our employees well. & 0.6812 & \\
\hline & $\begin{array}{l}\text { The decision-making process in our } \\
\text { organization is generally democratic. }\end{array}$ & 0.7492 & \\
\hline
\end{tabular}

The results of analyzing the relationship significance of each variable used in this study are shown in Table 3.

Table 3 Results of correlation analysis of variables

\begin{tabular}{|c|l|l|l|l|l|}
\hline & trust & $\begin{array}{c}\text { Servant } \\
\text { Leadership }\end{array}$ & $\begin{array}{c}\text { Job } \\
\text { satisfaction } \\
\text { satisfaction }\end{array}$ & Remark \\
\hline $\begin{array}{c}\text { Servant } \\
\text { trust }\end{array}$ & 1.0000 & -0.1337 & 1.0000 & & \\
\hline $\begin{array}{c}\text { Job satisfaction } \\
\text { satisfaction }\end{array}$ & 0.1152 & 0.2207 & 1.0000 & & \\
\hline Organizational & -0.0134 & 0.1854 & $0.2681 *$ & 1.0000 & \\
\hline
\end{tabular}

As shown in Table 3, trust and servant leadership showed a high correlation, and the significance of the relationship with other variables was low. Compared to previous studies, this was analyzed to be at a similar level.

Regression analysis was performed to find out the fitness of the research model used in this study. The regression analysis result was 0.4280 , and the F value indicating the fit of the model was $14.6534, \mathrm{p}<0.001$. This means that the research model was statistically appropriate. 
Effects of Servant Leadership of Consumer's Cooperative Manager on the

Job Satisfaction and Organizational Commitment

Table 4 Results of analysis of fitness of research model

\begin{tabular}{|c|c|c|c|c|}
\hline & B & Beta & t & $\begin{array}{l}\text { Significance } \\
\text { probability(p) }\end{array}$ \\
\hline (Constant) & 1.7888 & & $4.1183 \quad * * *$ & 0.0001 \\
\hline trust & -0.1665 & -0.2444 & $-2.7046 \quad * * *$ & 0.0086 \\
\hline $\begin{array}{c}\text { Servant } \\
\text { Leadership }\end{array}$ & -0.2116 & -0.2326 & $-2.5065 \quad * *$ & 0.0146 \\
\hline Job satisfaction & 0.2882 & 0.3492 & $3.6950 \quad * * *$ & 0.0004 \\
\hline $\begin{array}{c}\text { Organizational } \\
\text { satisfaction }\end{array}$ & 0.5791 & 0.4913 & $5.2972 \quad * * *$ & 0.0000 \\
\hline \multicolumn{5}{|c|}{$R^{2}=0.4280, \mathrm{~F}=14.6534, \mathrm{p}=0.0000$} \\
\hline \multicolumn{5}{|c|}{ Dependent variable: job satisfaction } \\
\hline
\end{tabular}

The variable affecting job satisfaction was calculated as $p<0.01$. In addition, in order to find out the effect of job satisfaction on organizational commitment, job satisfaction was selected as an independent variable, organizational commitment was selected as a dependent variable, and a regression analysis was conducted. The regression analysis result was found to be 0.1024 , and the F value indicating the fit of the model was calculated as 9.3306 .

Table 5 Relationship between job satisfaction and organizational commitment

\begin{tabular}{|c|c|c|c|c|}
\hline & B & Beta & $\mathbf{t}$ & $\begin{array}{c}\text { Significance } \\
\text { probability(p) }\end{array}$ \\
\hline (Constant) & 1.9521 & & $4.5356 \quad * * *$ & 0.0000 \\
\hline Job satisfaction & 0.3568 & 0.3387 & $3.0546 \quad * * *$ & 0.0032 \\
\hline & $R^{2}=0.1024, \mathrm{~F}=9.3306, \mathrm{p}=0.0032$ \\
\hline & Dependent variable: Organizational commitment \\
\hline
\end{tabular}

The data processing and analysis of this study used the SPSS 18.0 package. Factor Analysis and Reliability Analysis were conducted to verify the validity and reliability of the measurement tool, and t-test and ANOVA were conducted to examine servant leadership, trust, and job satisfaction. .

\section{CONCLUSION}

It has been partially confirmed that Servant Leadership affects employees' job satisfaction. The components of Servant Leadership, such as listening-job satisfaction, humility-job satisfaction, were adopted, and autonomy, which was considered an important part, was not adopted. 
It has also been confirmed that the Servant Leadership affects trust. Listening-trust, autonomy-trust were confirmed, and the humble-trust section was not confirmed, which seems to be a problem of organizational culture that has been established for a long time. In the relationship between trust and job satisfaction, the effect of trust was not confirmed. As shown in this study, when the Servant Leadership of a leader is demonstrated, employees follow the leader, and it is confirmed that they are satisfied with the organization as well as job satisfaction. In many previous studies, it was studied that trust has a mediating effect, but in this study, it was confirmed that trust alone did not complete job satisfaction. It can be said that this was caused by too many parts that workers need to manage and care about, such as performance and work processing.

In many cases, we know that the reasons for leaving a job are job insecurity and low wages due to performance, but conflict with leaders should be recognized as one of the main reasons. In order to resolve such conflicts and problems, it can be seen that the role of a leader prepared as a Servant Leadership is important to provide a working environment to do the best in one's job and role.

\section{ACKNOWLEDGEMENT}

This work was supported by the Jungwon University Research Grant (2019-024).

\section{REFERENCES}

[1] Van Dierendonck, D., Servant leadership: A review and synthesis. Journal of management, 2011.37(4): p. 1228-1261.

[2] Russell, R.F. and A.G. Stone, A review of servant leadership attributes: Developing a practical model. Leadership \& Organization Development Journal, 2002.

[3] Russell, R.F., The role of values in servant leadership. Leadership \& Organization Development Journal, 2001.

[4] Dennis, R.S. and M. Bocarnea, Development of the servant leadership assessment instrument. Leadership \& organization development journal, 2005.

[5] Sendjaya, S., J.C. Sarros, and J.C. Santora, Defining and measuring servant leadership behaviour in organizations. Journal of Management studies, 2008. 45(2): p. 402-424.

[6] Sendjaya, S. and J.C. Sarros, Servant leadership: Its origin, development, and application in organizations. Journal of Leadership \& Organizational Studies, 2002. 9(2): p. 5764.

[7] Farling, M.L., A.G. Stone, and B.E. Winston, Servant leadership: Setting the stage for empirical research. Journal of leadership studies, 1999. 6(1-2): p. 49-72.

[8] Barbuto Jr, J.E. and D.W. Wheeler, Scale development and construct clarification of servant leadership. Group \& Organization Management, 2006. 31(3): p. 300-326.

[9] Graham, J.W., Servant-leadership in organizations: Inspirational and moral. The Leadership Quarterly, 1991.2(2): p. 105-119.

[10] Greenleaf, R.K., The power of servant-leadership: Essays. 1998: Berrett-Koehler Publishers. 